\title{
Synthesis of acylated nucleosides and ribonic-1,4-lactones as inhibitors of trypanosomal glyceraldehyde-3-phosphate dehydrogenase (gGAPDH)
}

\author{
Marcus M. Sá, ${ }^{a}$ Gustavo P. Silveira, ${ }^{a}$ Marcelo S. Castilho, ${ }^{b}$ Fernando Pavãob, and Glaucius \\ Oliva $^{b}$ \\ ${ }^{a}$ Departamento de Química, Universidade Federal de Santa Catarina, Florianópolis, SC, \\ 88040-900; ${ }^{b}$ Instituto de Física, Universidade de São Paulo, São Carlos, SP, 13560-250 \\ E-mail: $\underline{\text { ma@gmc.ufsc.br }}$
}

\section{Dedicated to Professor Al Padwa on the occasion of his $65^{\text {th }}$ birthday, with regards and best wishes}

(received 30 May 02; accepted 12 Aug 02; published on the web 20 Aug 02)

\begin{abstract}
The synthesis of a representative group of substituted nucleosides and ribonic-1,4-lactones as potential inhibitors of trypanosomal enzyme gGAPDH is described. The novel 5-acylribonic-1,4lactones were easily obtained from ribonic lactone by a three-step procedure involving protection-deprotection protocols, in good overall yields. All compounds synthesized were subjected to inhibitory assay against gGAPDH, the most active being those carrying aromatic groups attached to the ribose ring. Other structural features responsible for the observed activities are also discussed.
\end{abstract}

Keywords: Acyl nucleosides, ribonic lactones, 5-acylribonic-1,4-lactones, gGAPDH inhibition

\section{Introduction}

Chagas' disease is an infection caused by the protozoan Trypanosoma cruzi and represents a serious health problem in the American continent. ${ }^{1,2}$ It is endemic in more than 20 countries, with 16-18 million people infected and 100 million at risk. T. cruzi is transmitted to humans by blood-sucking vector bugs or, more recently, by transfusion of infected blood, and no effective chemotherapy is currently available. ${ }^{3}$

One promising approach to combat the trypomastigote form of $T$. cruzi is through selective inhibition of enzymes or receptors that participate in important biochemical processes. Trypanosomal glycosomal glyceraldehyde-3-phosphate dehydrogenase (gGAPDH) has been selected as a potential target ${ }^{4}$ in a structure-based drug design approach, ${ }^{5}$ considering the 
essential role of this enzyme in the metabolism of glucose by the parasite. ${ }^{6}$ Moreover, in silico modeling of this pathway has indicated that the reaction catalyzed by gGAPDH is one of the preferred steps for inhibition. ${ }^{7}$ In view of the structural differences with respect to the homologous human enzyme, the adenosine portion of the $\mathrm{NAD}^{+}$cofactor site in gGAPDH was mapped and chosen as the target for planning possible inhibitors against this enzyme. ${ }^{5,8,9}$ Therefore, computational searching using the DOCK $3.5 \operatorname{program}^{10}$ identified a set of structures which represent potential candidates for gGAPDH inhibition. Amongst the ranked compounds, benzoyl-substituted nucleosides derived from inosine (I) and guanosine (II) were selected for chemical synthesis and biological evaluation. We report herein the preparation and inhibitory activity of the acylated nucleosides I, II and the related D-ribonic-1,4-lactones III as scaffolds for gGAPDH inhibitors. The development of a simple synthetic methodology for obtaining novel 5-acylribonic-1,4-lactones is also fully described.
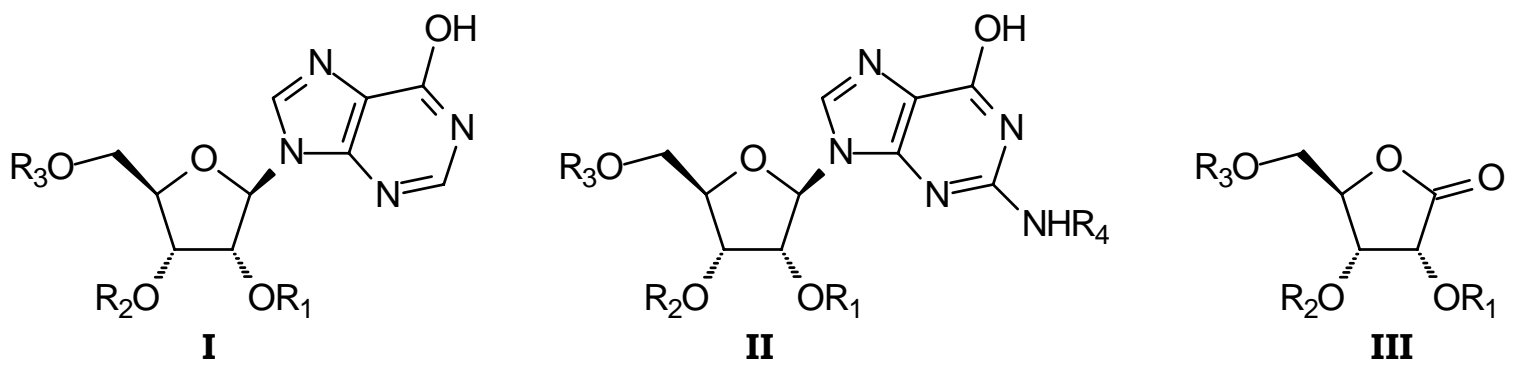

$R_{1}, R_{2}, R_{3}=H$, Acyl, Alkyl; $R_{4}=H, P h c O$

\section{Results and Discussion}

A representative group of nucleosides was synthesized, starting from commercially available inosine 1 and guanosine 2, in order to evaluate the effect of different substitution patterns at the 2-, 3- and 5-positions of the ribose ring and at the 6'-position of the purine moiety as well. The triacylated nucleosides 3-8 were easily obtained by treating inosine or guanosine with an excess of the respective acid chloride (or acetic anhydride) in pyridine as solvent, under mild heating (Schemes 1 and 2). ${ }^{11,12}$ Higher temperatures promote N-benzoylation of guanosine and triacetyl guanosine, producing the peracylated compounds $\mathbf{9}$ and 10, respectively, as previously reported (Scheme 2). ${ }^{13,14}$ 
<smiles>OC[C@H]1O[C@@H](n2cnc3c(O)ncnc32)[C@H](O)[C@@H]1O</smiles>

1

Conditions: a. $\mathrm{ArCOCl}$, py, $60^{\circ} \mathrm{C}$ (for 3-5: 85-98\%) or $\mathrm{Ac}_{2} \mathrm{O}$, py, $90^{\circ} \mathrm{C}$ (for 6: $95 \%$ ).<smiles>[R]C(=O)OC[C@H]1O[C@@H](n2cnc3c(O)ncnc32)[C@H](OC([R])=O)[C@@H]1OC([R])=O</smiles>

$3 \mathrm{R}=\mathrm{Ph}$

$4 \mathrm{R}=4-\mathrm{CIPh}$

$5 \mathrm{R}=3,5-\left(\mathrm{NO}_{2}\right)_{2} \mathrm{Ph}$

$6 \mathrm{R}=\mathrm{CH}_{3}$

\section{Scheme 1}

Selective 5-substituted nucleosides were readily obtained through protection-deprotection protocols using the 2,3-O-isopropylidene-inosine $\mathbf{1 1}$ as the common intermediate. ${ }^{15}$ Benzoylation $^{15}$ of the 2,3-protected inosine $\mathbf{1 1}$ followed by acidic hydrolysis ${ }^{16}$ of the isopropylidene group in $\mathbf{1 2}$ afforded 5-benzoylated inosine $\mathbf{1 3}$ in good overall yields (Scheme 3).

The carboxyl analogs 14-17 were obtained by firstly oxidizing the primary alcoholic function in 11 with $\mathrm{CrO}_{3}$ in glacial acetic acid, ${ }^{17}$ yielding the protected acid 14, which was directly deprotected with aqueous $\mathrm{HCl}$ to give 15, or esterified (via the acid chloride) to the isopropyl ester 16. Subsequent deprotection furnished the dihydroxy ester $\mathbf{1 7}$ in reasonable yields (Scheme 3).<smiles>CC(C)C1OC(CO)[C@@H](O)C1n1cnc2c(O)nc(N)nc21</smiles><smiles>[R]C(=[R])O[C@@H]1[C@@H](COC([R])=O)O[C@@H](n2cnc3c(O)nc(N)nc32)[C@@H]1OC([R])=O</smiles><smiles>O=C(Nc1nc(O)c2ncn(C3OC(COC(=O)c4ccccc4)C(OC(=O)c4ccccc4)C3OC(=O)c3ccccc3)c2n1)c1ccccc1</smiles><smiles>C=P[I+](C)(C)C</smiles>

Conditions: a. $\mathrm{PhCOCl}$, py, $50-60^{\circ} \mathrm{C}(\mathrm{R}=\mathrm{Ph}: 75 \%)$ or $\mathrm{Ac}_{2} \mathrm{O}$, py, $80^{\circ} \mathrm{C}\left(\mathrm{R}=\mathrm{CH}_{3}: 85 \%\right)$; b. $\mathrm{PhCOCl}$, py, $90^{\circ} \mathrm{C}(88 \%)$; c. $\mathrm{PhCOCl}$, py, $75^{\circ} \mathrm{C}(86 \%)$.

\section{Scheme 2}



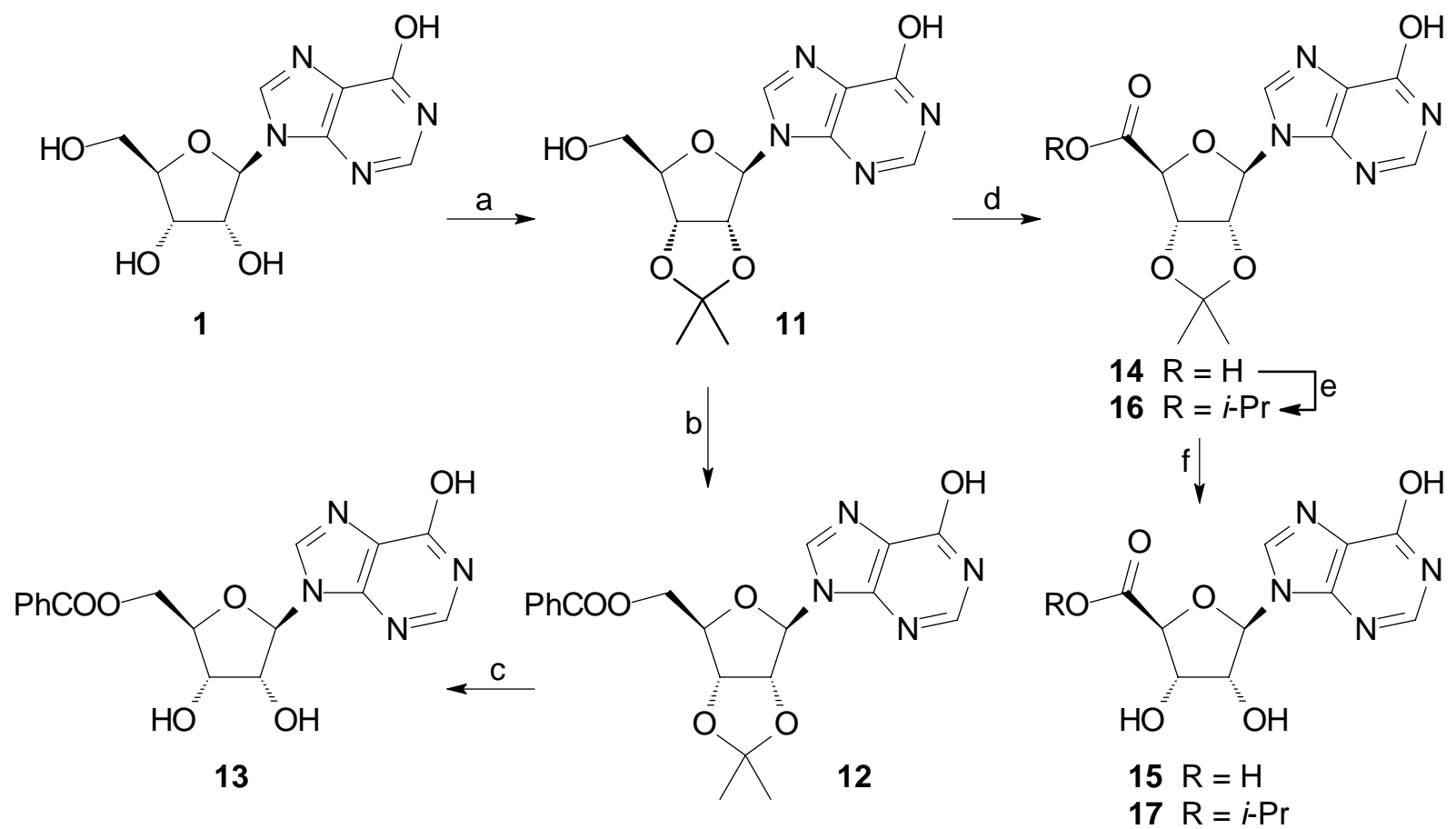

Conditions: a. $p$ - $\mathrm{TsOH}, \mathrm{Me}_{2} \mathrm{CO}$, rt (66\%); b. $\mathrm{PhCOCl}$, py, $60^{\circ} \mathrm{C}(78 \%) ; \mathrm{c}$. $\mathrm{AcOH}-\mathrm{H}_{2} \mathrm{O}(1: 9), 90^{\circ} \mathrm{C}$ (68\%); d. $\mathrm{CrO}_{3}, \mathrm{AcOH}$, rt (58\%); e. $\mathrm{SOCl}_{2},\left(\mathrm{CH}_{3}\right)_{2} \mathrm{CHOH}$, rt (71\%); f. $1 \mathrm{M} \mathrm{HCl}, 80^{\circ} \mathrm{C}(70-75 \%)$.

\section{Scheme 3}

Carbohydrates are among the most versatile chiral pools employed in the synthesis of biologically important compounds. ${ }^{18}$ Ribose analogs selectively substituted with acyl groups, and structurally related to the nucleosides prepared above, are good candidates for inhibitory assays as they provide a simple way to investigate the influence of a purine ring on the inhibitory activity. Moreover, carbohydrates and derivatives are usually fairly soluble in water, a required property not always found in synthetically modified nucleosides (vide infra). Therefore we chose the commercially accessible D-ribonic-1,4-lactone $\mathbf{1 8}$ as a simple scaffold for generating a representative group of acylated ribose derivatives. Ribonic-1,4-lactone $\mathbf{1 8}$ has been widely used as starting material for the synthesis of heterocycles and natural products. ${ }^{19,20}$ Surprisingly, as far as we are concerned, no general method is available for the synthesis of selectively monoacylated ribonic-1,4-lactones. ${ }^{21}$ Aside from the previously reported tribenzoyl lactone 19, ${ }^{22}$ no simple peracylated derivatives of ribonic-1,4-lactone are known. This fact stimulated a more detailed investigation concerning the development of simple methodologies for obtaining monoacylated and peracylated D-ribonic-1,4-lactones as synthetic targets.

A representative group of triacylribonic-1,4-lactones 19-23 was achieved by treating 18 with a four-fold excess of an acid chloride in pyridine, in excellent yields (Scheme 4). All peracylated compounds 19-23 are stable crystalline solids, easily purified by recrystallization from appropriate solvents (see Experimental Section). 

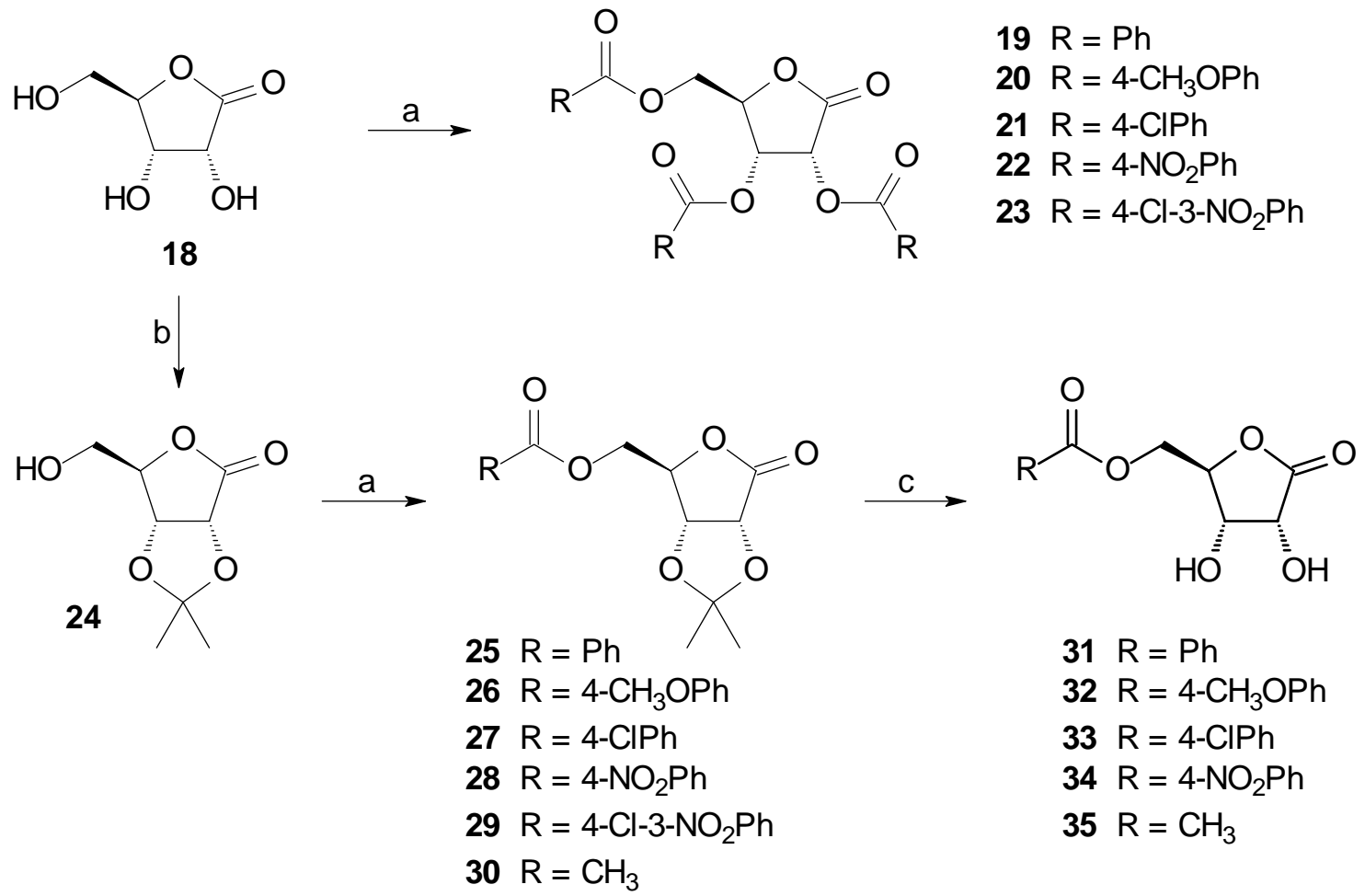
$31 \mathrm{R}=\mathrm{Ph}$
$32 \mathrm{R}=4-\mathrm{CH}_{3} \mathrm{OPh}$
$33 \mathrm{R}=4-\mathrm{ClPh}$
$34 \mathrm{R}=4-\mathrm{NO}_{2} \mathrm{Ph}$
$35 \mathrm{R}=\mathrm{CH}_{3}$

Conditions: a. RCOCl, py, rt (for 19-23: 82-95\%; for 25-29: 80-99\%) or $\mathrm{Ac}_{2} \mathrm{O}$, py, rt (for $\mathbf{3 0}$

$90 \%)$; b. $\mathrm{Me}_{2} \mathrm{CO}, \mathrm{HCl}$, rt (88\%); c. TFA- $\mathrm{H}_{2} \mathrm{O}(1: 1), 40^{\circ} \mathrm{C}$ or $\mathrm{AcOH}-\mathrm{H}_{2} \mathrm{O}(1: 9), 90^{\circ} \mathrm{C}(54-99 \%)$.

\section{Scheme 4}

Next, we examined the preparation of a small collection of 5-acylated ribonic-1,4-lactones by a simple general method. While the more reactive primary hydroxyl group at the 5-position in 18 is selectively alkylated ${ }^{23}$ or silylated ${ }^{24}$ with trityl chloride or $t$-butyldimethylsilyl chloride, respectively, the initial approach for directly acylating 18 with 0.9 equiv. of 4-nitrobenzoyl chloride under mild conditions $\left(20^{\circ} \mathrm{C}, 45\right.$ minutes) was unsuccessful. The triacyl derivative 22 was the only compound detectable in the ${ }^{1} \mathrm{H}-\mathrm{NMR}$ of the crude reaction, being isolated in $30 \%$ yield. These results clearly indicated that a protection-deprotection protocol would be necessary to avoid acylation of both 2,3-positions. Therefore, a three-step procedure involving initial protection of the 2,3-diol- group in ribonic-1,4-lactone 18, followed by 5-acylation and subsequent 2,3-deprotection should afford the required 5-acyl lactones.

2,3-Isopropylideneribonic-1,4-lactone $\mathbf{2 4}$ is a versatile compound extensively used as a synthetic building block. ${ }^{19,20}$ The synthesis of $\mathbf{2 4}$ usually employs treatment of $\mathbf{1 8}$ with acetone in acidic media and has been thoroughly reported in the literature, although with many variations in the reaction conditions, work up and chemical yields. ${ }^{21,25-29}$ We experienced difficulties in reproducing some of these results, and after some trial it was found that the isopropylidene lactone $\mathbf{2 4}$ could be produced cleanly on a multi-gram scale by first quenching the acidic reaction mixture with potassium carbonate, followed by filtering the suspension and washing the filtrate 
with aqueous sodium bicarbonate. The product crystallized from ethanol in $88 \%$ yield as crystals with definite melting point $\left(136-137^{\circ} \mathrm{C}\right){ }^{26-29} 5$-Acylation of the protected lactone 24 was carried out under standard conditions ( $\mathrm{ArCOCl}$, py), furnishing in high yields the expected 5-acyl-2,3isopropylidene lactones 25-29 as crystalline solids. Acetylation of $\mathbf{2 4}$ with acetic anhydride and pyridine was effected similarly, to give the known ${ }^{29} 5$-acetyl derivative $\mathbf{3 0}$ in high yield (Scheme 4).

2,3-Diol deprotection of 5-acyl-2,3-isopropylidene lactones $\mathbf{2 5}$ and $\mathbf{2 8}$ to the respective 5acyl-1,4-ribonic lactones was initially attempted with iodine in methanol under essentially neutral conditions, ${ }^{30}$ but the aqueous work up required to remove the excess of reagents made the isolation of the expected 5-acylribonolactones difficult owing to their high solubility in water. Acidic hydrolysis employing volatile reagents, easily removed by reduced pressure to facilitate product isolation, were then tested with lactone 25 . While the use of $1 \mathrm{M} \mathrm{HCl}$ at $70^{\circ} \mathrm{C}$ was inefficient owing to the low solubility of the starting protected lactone 25, a complete deprotection of the 2,3-diol function could be achieved with a $10 \%$ acetic acid solution under heating, ${ }^{16}$ giving the 5-benzoyl lactone 31 in moderate yield (Scheme 4). Milder conditions and good- to excellent yields were obtained when acetic acid was replaced by trifluoroacetic acid (TFA), ${ }^{21}$ promoting the clean hydrolysis of the protected lactones $\mathbf{2 5 - 2 8}$ and $\mathbf{3 0}$ to the expected products 31-35. However, it was not possible successfully to carry out the hydrolysis of protected lactone $\mathbf{2 9}$ owing to its low solubility in the reaction medium. Increasing the amount of TFA and raising the temperature resulted in partial decomposition of $\mathbf{2 9}$, as indicated by the ${ }^{1} \mathrm{H}-$ NMR of the crude reaction mixture.

All the nucleosides and ribonic lactones prepared above were screened for their inhibitory activity against gGAPDH using an established protocol, ${ }^{8}$ with the results presented in Tables 1 and 2. Determination of IC50 for most of the active compounds was precluded owing to their reduced solubility in the solvent system used in the assay $(10 \%$ DMSO in Tris- $\mathrm{HCl}$ buffer, $\mathrm{pH}$ 8.6). While a quantitative evaluation was not possible at this time, some interesting remarks can be made from the data collected in Tables 1 and 2 . Nucleosides $\mathbf{4 , 5}$ and $\mathbf{8}$, fully substituted with aromatic groups at the 2-, 3-, and 5-positions, were the most active compounds, inhibiting 31$42 \%$ of gGAPDH at concentrations ranging from 125 to $165 \mu M$ (Table 1). Moreover, the presence of polar groups (nitro and chloro) on the aromatic ring seems to increase the observed activity (compare the inhibitors 4, 5 with inactive 3, for example). An effect of substitution at the purine ring was also verified, with the tribenzoylguanosine 7 (containing a free amino group at the 6'-position) being one of the most active compounds, whereas the related N-benzoylated guanosine 9 and tribenzoylinosine 3 showed no activity. Compounds bearing only one benzene ring (5-acyl nucleosides $\mathbf{1 2}$ and 13) were also inactive, as well as the somewhat more watersoluble carboxyl derivatives 14-17. 
Table 1. Inhibitory Activity of Acylinosine and Acylguanosine Derivatives ${ }^{\#}$

\begin{tabular}{ccccc}
\hline Compound & $\mathrm{R}_{1}$ & $\mathrm{R}$ & Conc. $(\mu M)$ & Inhibition (\%) \\
\hline $\mathbf{4}$ & $\mathrm{H}$ & $4-\mathrm{ClPh}$ & 145 & 31 \\
$\mathbf{5}$ & $\mathrm{H}$ & $3,5-\left(\mathrm{NO}_{2}\right)_{2} \mathrm{Ph}$ & 165 & 42 \\
$\mathbf{8}$ & $\mathrm{NH}_{2}$ & $\mathrm{Ph}$ & 125 & 35 \\
\hline
\end{tabular}

${ }^{\#}$ Compounds considered inactive (i.e., when the concentration required to inhibit gGAPDH to any extent was higher than $280 \mu M$ ) were omitted.

Table 2. Inhibitory Activity of Ribonic-1,4-lactones ${ }^{\#}$

\begin{tabular}{cccc}
\hline Compound & $\mathrm{R}$ & Conc. $(\mu M)$ & Inhibition (\%) \\
\hline $\mathbf{2 0}$ & $4-\mathrm{CH}_{3} \mathrm{OPh}$ & 255 & 50 \\
$\mathbf{2 2}$ & $4-\mathrm{NO}_{2} \mathrm{Ph}$ & 115 & 18 \\
$\mathbf{2 3}$ & $4-\mathrm{Cl}-3-\mathrm{NO}_{2} \mathrm{Ph}$ & 230 & 23 \\
$\mathbf{2 8}$ & $4-\mathrm{NO}_{2} \mathrm{Ph}$ & 325 & 4 \\
$\mathbf{2 9}$ & $4-\mathrm{Cl}-3-\mathrm{NO}_{2} \mathrm{Ph}$ & 215 & 20 \\
$\mathbf{3 4}$ & $4-\mathrm{NO}_{2} \mathrm{Ph}$ & 335 & 8 \\
\hline
\end{tabular}

${ }^{\#}$ Compounds considered inactive (i.e., when the concentration required to inhibit gGAPDH to any extent was higher than $280 \mu M$ ) were omitted.

Analogous results were obtained for the lactones 19-35, the triaroyl derivatives containing polar groups attached to the aromatic nucleus (methoxy-, nitro- and chloro-) being the most active of the series (compare inhibitors 20, 22 and 23 in Table 2 with inactive 19, for example). Although less active than the triacyl nucleosides $\mathbf{4}, \mathbf{5}$ and $\mathbf{8}$, the inhibitory activity showed by the triacyl lactones 20, 22 and 23 are of the same magnitude, 18-50\% at concentrations ranging from 115 to $255 \mu M$. On the other hand, compounds substituted with a single aromatic group (5-acyl lactones 25-35) were very poor inhibitors, with little, if any, activity. The exception was the 5(4-chloro-3-nitrobenzoyl)-2,3-isopropylidene lactone, 29, which showed moderate activity (Table 2).

\section{Conclusions}

A representative series of substituted nucleosides and ribonic lactones was prepared in good to excellent yields, using simple conditions and inexpensive reagents. Of particular interest was the synthesis of novel 5-acylribonic-1,4-lactones, easily obtained by a three-step procedure in 35$55 \%$ overall yields. Some of the synthesized nucleosides and ribonic lactones showed moderate inhibitory activity against gGAPDH. Triaroyl derivatives bearing polar groups attached to the aromatic nucleus were the most active, whereas monosubstituted compounds and those 
substituted with small groups such as acetyl and isopropylidene were very poor inhibitors. Furthermore, a triacylnucleoside substituted with an amino group at the 6'-position of the purine ring showed enhanced activity. Overall, the triacyl nucleosides 4, 5 and 8 were the most active compounds, although the inhibitory activity showed by the related triacyl lactones 20, 22 and 23 were of comparable magnitude. These results point out the possibility for developing novel gGAPDH inhibitors using ribonic lactone derivatives as simpler structural scaffolds.

It is interesting to note that the most active compounds (nucleosides $\mathbf{4 , 5 , 8}$, and lactones $\mathbf{2 0}$, 22, 23, and 29) showed, in general, limited solubility in water, while very poor inhibitors such as the carboxyl-containing nucleosides 14-17 and 5-acylribonic lactones 31-35 were highly watersoluble. Consequently, planning the next generation of potential gGAPDH inhibitors will have to take both properties into account, and detailed investigations will be reported in due course.

\section{Experimental Section}

General Procedures. All chemicals were of reagent grade and were used as received. Melting points are uncorrected. IR spectra were measured with a Perkin-Elmer FTIR-16 PC spectrophotometer using $\mathrm{KBr}$ for solids and film for liquid samples. ${ }^{1} \mathrm{H}-\mathrm{NMR}(200 \mathrm{MHz})$ and ${ }^{13} \mathrm{C}-\mathrm{NMR}\left(50 \mathrm{MHz}\right.$ ) spectra were recorded with a Bruker AC-200F spectrometer using $\mathrm{CDCl}_{3}$ or $\mathrm{DMSO}^{-\mathrm{d}_{6}}$ as solvent and TMS as internal standard. Elemental analyses were performed with a CHN Perkin-Elmer 2400 by UFSC-Central Analítica, Departamento de Química, Florianópolis, SC, Brazil. Compounds 3, 6-17, and 30 were prepared according to the described methods ${ }^{11-17,29}$

2,3,5-O-Tri-(4-chlorobenzoyl)inosine (4). To a stirring suspension of $0.30 \mathrm{~g}$ of inosine $(1.1 \mathrm{mmol})$ in $6 \mathrm{~mL}$ of anhydrous pyridine under $\mathrm{N}_{2}$ at $25^{\circ} \mathrm{C}$ was added $0.6 \mathrm{~mL}$ of 4 chlorobenzoyl chloride $(4.7 \mathrm{mmol})$. The resulting mixture was immediately immersed in a preheated oil bath at $55-60^{\circ} \mathrm{C}$ and heated for 3 hours. After cooling, the reaction was stirred at $25^{\circ} \mathrm{C}$ for an additional 18 hours. The excess of pyridine was distilled off, the residual oil was dissolved in $\mathrm{CH}_{2} \mathrm{Cl}_{2}$ and the organic phase was washed with $10 \%$ aqueous $\mathrm{NaHCO}_{3}$ and with $\mathrm{H}_{2} \mathrm{O}$, dried with $\mathrm{Na}_{2} \mathrm{SO}_{4}$, filtered and concentrated to give a clear oil which solidified on standing. Recrystallization in dichloromethane-hexane afforded crystalline solid (84\% yield), m.p. $147-149^{\circ} \mathrm{C}$; IR: 1730,1594 and $1268 \mathrm{~cm}^{-1} ;{ }^{1} \mathrm{H}-\mathrm{NMR}\left(\mathrm{CDCl}_{3}\right): \delta 4.65-4.85(\mathrm{~m}, 3 \mathrm{H}), 6.13(\mathrm{t}$, $1 \mathrm{H}, \mathrm{J}=5.5 \mathrm{~Hz}), 6.33(\mathrm{~m}, 1 \mathrm{H}), 6.57(\mathrm{~d}, 1 \mathrm{H}, \mathrm{J}=4.5 \mathrm{~Hz}), 7.50-7.60(\mathrm{~m}, 6 \mathrm{H}), 7.85-8.00(\mathrm{~m}, 6 \mathrm{H})$, $8.10(\mathrm{~s}, 1 \mathrm{H})$ and $8.53(\mathrm{~s}, 1 \mathrm{H})$. Anal. Calcd. for $\mathrm{C}_{31} \mathrm{H}_{21} \mathrm{Cl}_{3} \mathrm{~N}_{4} \mathrm{O}_{8}: \mathrm{C}, 54.45 ; \mathrm{H}, 3.09 ; \mathrm{N}, 8.19$; Found: C, 54.23; H, 3.21; N, 8.17.

2,3,5-O-Tri-(3,5-dinitrobenzoyl)inosine (5). To a stirring suspension of $0.50 \mathrm{~g}$ of inosine $(1.85 \mathrm{mmol})$ in $10 \mathrm{~mL}$ of anhydrous pyridine under $\mathrm{N}_{2}$ at $25^{\circ} \mathrm{C}$ was added $1.80 \mathrm{~g}$ of 3,5 dinitrobenzoyl chloride $(7.8 \mathrm{mmol})$. The resulting mixture was immediately immersed in a preheated oil bath at $60-70^{\circ} \mathrm{C}$ and heated for 3 hours. After cooling, the reaction was stirred at $25^{\circ} \mathrm{C}$ for an additional 18 hours. The excess of pyridine was distilled off and the residual material 
was triturated with ethyl acetate and methanol. The clear yellow solid obtained was filtered and thoroughly washed with water, methanol and ethyl ether to remove traces of pyridine. An amorphous solid was obtained (94\% yield), m.p. $174-177^{\circ} \mathrm{C}$ (decomp.); IR: 1742, 1700, 1545 and $1345 \mathrm{~cm}^{-1} ;{ }^{1} \mathrm{H}-\mathrm{NMR}\left(\mathrm{DMSO}-\mathrm{d}_{6}\right): \delta 4.85(\mathrm{dd}, 1 \mathrm{H}, \mathrm{J}=5.3$ and $12.0 \mathrm{~Hz}), 4.96(\mathrm{dd}, 1 \mathrm{H}, \mathrm{J}=3.5$ and $12.0 \mathrm{~Hz}), 5.11(\mathrm{~m}, 1 \mathrm{H}), 6.34(\mathrm{~m}, 1 \mathrm{H}), 6.47(\mathrm{dd}, 1 \mathrm{H}, \mathrm{J}=4.3$ and $6.2 \mathrm{~Hz}), 6.74(\mathrm{~d}, 1 \mathrm{H}, \mathrm{J}=4.3$ $\mathrm{Hz}), 7.94(\mathrm{~s}, 1 \mathrm{H}), 8.38(\mathrm{~s}, 1 \mathrm{H}), 8.80-8.95(\mathrm{~m}, 6 \mathrm{H})$ and $9.06(\mathrm{~m}, 3 \mathrm{H})$. Anal. Calcd. for $\mathrm{C}_{31} \mathrm{H}_{18} \mathrm{~N}_{10} \mathrm{O}_{20}$ : C, 43.78; H, 2.13; N, 16.47; Found: C, 43.98; H, 2.08; N, 16.66.

\section{General procedure for the synthesis of 2,3,5-O-triacylribonic-1,4-lactones (19-23)}

A solution containing D-ribonic-1,4-lactone $18(0.33 \mathrm{mmol})$ and an appropriated acyl chloride $(1.5 \mathrm{mmol})$ in $0.5 \mathrm{~mL}$ of anhydrous pyridine and $0.5 \mathrm{~mL}$ of anhydrous $\mathrm{CHCl}_{3}$ was stirred under $\mathrm{N}_{2}$ at $25^{\circ} \mathrm{C}$ for 24 hours. The mixture obtained was dissolved in $\mathrm{CH}_{2} \mathrm{Cl}_{2}$ and the organic phase was washed with $5 \%$ aqueous $\mathrm{HCl}, 5 \%$ aqueous $\mathrm{NaHCO}_{3}$ and $\mathrm{H}_{2} \mathrm{O}$, dried with $\mathrm{Na}_{2} \mathrm{SO}_{4}$, filtered and concentrated to give a clear oil which solidified on standing. Recrystallization in the solvent indicated below afforded the triacyl derivatives as crystalline products.

2,3,5-O-Tribenzoylribonic-1,4-lactone (19). Recrystallized in acetone-ethanol (90\% yield), m.p. $148^{\circ} \mathrm{C}$ (lit. $\left.{ }^{22} 148^{\circ} \mathrm{C}\right)$; IR: 1772 and $1722 \mathrm{~cm}^{-1} ;{ }^{1} \mathrm{H}-\mathrm{NMR}\left(\mathrm{CDCl}_{3}\right): \delta 4.65-4.90(\mathrm{~m}, 2 \mathrm{H}), 5.09$ $(\mathrm{m}, 1 \mathrm{H}), 5.94(\mathrm{~d}, 1 \mathrm{H}, \mathrm{J}=6.4 \mathrm{~Hz}), 6.18(\mathrm{~d}, 1 \mathrm{H}, \mathrm{J}=6.4 \mathrm{~Hz})$ and 7.30-8.15 (m, 15H). Anal. calcd. for $\mathrm{C}_{26} \mathrm{H}_{20} \mathrm{O}_{8}$ : C, 67.82; $\mathrm{H}, 4.38$; Found: C, 67.87; H, 4.45.

2,3,5-O-Tri(4-methoxybenzoyl)ribonic-1,4-lactone (20). Recrystallized in acetone-ethanol (92\% yield), m.p. $113-116^{\circ} \mathrm{C}$; IR: 1784,1726 and $1380 \mathrm{~cm}^{-1} ;{ }^{1} \mathrm{H}-\mathrm{NMR}\left(\mathrm{CDCl}_{3}\right): \delta 3.85(\mathrm{~s}, 3 \mathrm{H})$ 4.60-4.85 (m, 2H), $5.04(\mathrm{~m}, 1 \mathrm{H}), 5.88(\mathrm{~d}, 1 \mathrm{H}, \mathrm{J}=6.3 \mathrm{~Hz}), 6.13(\mathrm{~d}, 1 \mathrm{H}, \mathrm{J}=6.3 \mathrm{~Hz}), 6.75-7.05$ $(\mathrm{m}, 6 \mathrm{H})$ and 7.78-8.10 (m, 6H). Anal. calcd. for $\mathrm{C}_{29} \mathrm{H}_{26} \mathrm{O}_{11}: \mathrm{C}, 63.27$; H, 4.76; Found: C, 63.25; $\mathrm{H}, 4.84$.

2,3,5-O-Tri-(4-chlorobenzoyl)ribonic-1,4-lactone (21). Recrystallized in ethanol (94\% yield), m.p. $148-149^{\circ} \mathrm{C}$; IR: 1788 and $1726 \mathrm{~cm}^{-1} ;{ }^{1} \mathrm{H}-\mathrm{NMR}\left(\mathrm{CDCl}_{3}\right)$ : $\delta 4.60-4.85(\mathrm{~m}, 2 \mathrm{H}), 5.07(\mathrm{~m}, 1 \mathrm{H})$, $5.92(\mathrm{~d}, 1 \mathrm{H}, \mathrm{J}=6.2 \mathrm{~Hz}), 6.13(\mathrm{~d}, 1 \mathrm{H}, \mathrm{J}=6.2 \mathrm{~Hz})$ and $7.33-8.08(\mathrm{~m}, 12 \mathrm{H})$. Anal. Calcd. for $\mathrm{C}_{26} \mathrm{H}_{17} \mathrm{Cl}_{3} \mathrm{O}_{8}$ : C, 55.39; H, 3.04; Found: C, 55.53; H, 3.09.

2,3,5-O-Tri-(4-nitrobenzoyl)ribonic-1,4-lactone (22). Recrystallized in acetone (95\% yield), m.p. $165-166^{\circ} \mathrm{C}$; IR: 1810, 1734, 1526 and $1354 \mathrm{~cm}^{-1} ;{ }^{1} \mathrm{H}-\mathrm{NMR}\left(\mathrm{CDCl}_{3}\right): \delta 4.86(\mathrm{~m}, 2 \mathrm{H}), 5.45$ $(\mathrm{m}, 1 \mathrm{H}), 6.08(\mathrm{~d}, 1 \mathrm{H}, \mathrm{J}=6.2 \mathrm{~Hz}), 6.43(\mathrm{~d}, 1 \mathrm{H}, \mathrm{J}=6.2 \mathrm{~Hz})$ and 8.10-8.50 (m, 12H). Anal. calcd. for $\mathrm{C}_{26} \mathrm{H}_{17} \mathrm{~N}_{3} \mathrm{O}_{14}$ : C, 52.45; H, 2.88; N, 7.06; Found: C, 52.60; H, 2.93; N, 6.97.

2,3,5-O-Tri-(4-chloro-3-nitrobenzoyl)ribonic-1,4-lactone (23). Recrystallized in ethanol (82\% yield), m.p. ${ }^{144-146}{ }^{\circ} \mathrm{C}$; IR: 1790, 1732,1536 and $1354 \mathrm{~cm}^{-1} ;{ }^{1} \mathrm{H}-\mathrm{NMR}\left(\mathrm{CDCl}_{3}\right): \delta 4.70-4.95$ $(\mathrm{m}, 2 \mathrm{H}), 5.07(\mathrm{~m}, 1 \mathrm{H}), 5.90(\mathrm{~d}, 1 \mathrm{H}, \mathrm{J}=6.3 \mathrm{~Hz}), 6.15(\mathrm{~d}, 1 \mathrm{H}, \mathrm{J}=6.3 \mathrm{~Hz})$ and $7.60-8.60(\mathrm{~m}, 9 \mathrm{H})$. Anal. Calcd. for $\mathrm{C}_{26} \mathrm{H}_{14} \mathrm{Cl}_{3} \mathrm{~N}_{3} \mathrm{O}_{14}$ : C, 44.69; H, 2.02; N, 6.01; Found: C, 44.81; H, 2.13; N, 6.14.

2,3-O-Isopropylideneribonic-1,4-lactone (24). A solution containing D-ribono-1,4-lactone 18 $(27.0 \mathrm{mmol})$ in $160 \mathrm{~mL}$ of acetone and $1.6 \mathrm{~mL}$ of concentrated $\mathrm{HCl}$ was stirred for 18 hours at $25^{\circ} \mathrm{C}$. The final suspension was neutralized with anhydrous $\mathrm{K}_{2} \mathrm{CO}_{3}$ and the mixture was filtered and concentrated in vacuo. The residue obtained was dissolved in $\mathrm{CH}_{2} \mathrm{Cl}_{2}$ and the organic phase 
was washed with saturated $\mathrm{NaHCO}_{3}$ and $\mathrm{H}_{2} \mathrm{O}$, dried with $\mathrm{Na}_{2} \mathrm{SO}_{4}$, filtered, concentrated and coevaporated with ethanol to give clear oil which solidified on standing. Recrystallization in ethanol afforded a crystalline product $(88 \%$ yield $)$, m.p. $136-137^{\circ} \mathrm{C}$ (lit. $\left.{ }^{27} 138-139^{\circ} \mathrm{C}\right) .{ }^{1} \mathrm{H}-\mathrm{NMR}$ data were identical with those reported. ${ }^{26,29}$

\section{General procedure for the synthesis of 5-O-acyl-2,3-O-isopropylideneribonic-1,4-lactones (25-29)}

A solution containing 2,3-O-isopropylidene-1,4-lactone $24(0.54 \mathrm{mmol})$ and an appropriate acyl chloride $(0.80 \mathrm{mmol})$ in $1.0 \mathrm{~mL}$ of anhydrous pyridine and $1.0 \mathrm{~mL}$ of anhydrous $\mathrm{CHCl}_{3}$ was stirred under $\mathrm{N}_{2}$ at $25^{\circ} \mathrm{C}$ for 24 hours. The mixture obtained was dissolved in $\mathrm{CH}_{2} \mathrm{Cl}_{2}$ and the organic phase was washed with $5 \%$ aqueous $\mathrm{HCl}, 5 \%$ aqueous $\mathrm{NaHCO}_{3}$ and $\mathrm{H}_{2} \mathrm{O}$, dried with $\mathrm{Na}_{2} \mathrm{SO}_{4}$, filtered and concentrated to give a clear oil which solidified on standing. Recrystallization in the solvent indicated below afforded the 5-acyl 2,3-protected lactones as crystalline products.

5-O-Benzoyl-2,3-O-isopropylideneribonic-1,4-lactone (25). Recrystallized in ethanol (99\% yield), m.p. $98-99^{\circ} \mathrm{C}$; IR: 1788, 1732 and $1382 \mathrm{~cm}^{-1}$; ${ }^{1} \mathrm{H}-\mathrm{NMR}\left(\mathrm{CDCl}_{3}\right): \delta 1.40(\mathrm{~s}, 3 \mathrm{H}), 1.51$ (s, $3 \mathrm{H}), 4.48(\mathrm{dd}, 1 \mathrm{H}, \mathrm{J}=2.0$ and $13.3 \mathrm{~Hz}), 4.63(\mathrm{dd}, 1 \mathrm{H}, \mathrm{J}=2.0$ and $13.3 \mathrm{~Hz}), 4.79(\mathrm{~m}, 2 \mathrm{H}), 4.92(\mathrm{t}$, $1 \mathrm{H}, \mathrm{J}=2.0 \mathrm{~Hz}), 7.48(\mathrm{t}, 2 \mathrm{H}, \mathrm{J}=8.6 \mathrm{~Hz}), 7.63(\mathrm{t}, 1 \mathrm{H}, \mathrm{J}=8.6 \mathrm{~Hz})$ and $7.95(\mathrm{~d}, 2 \mathrm{H}, 8.6 \mathrm{~Hz})$. Anal. calcd. for $\mathrm{C}_{15} \mathrm{H}_{16} \mathrm{O}_{6}$ : C, 61.64; H, 5.52; Found: C, 62.12; H, 5.60.

5-O-(4-Methoxybenzoyl)-2,3-O-isopropylideneribonic-1,4-lactone (26). Recrystallized in acetone-ethanol (99\% yield), m.p. 99-102 ${ }^{\circ} \mathrm{C}$; IR: 1782, 1726, 1384 and $1170 \mathrm{~cm}^{-1}$; ${ }^{1} \mathrm{H}-\mathrm{NMR}$ $\left(\mathrm{CDCl}_{3}\right): \delta 1.38(\mathrm{~s}, 3 \mathrm{H}), 1.50(\mathrm{~s}, 3 \mathrm{H}), 4.42(\mathrm{dd}, 1 \mathrm{H}, \mathrm{J}=2.0$ and $13.0 \mathrm{~Hz}), 4.68(\mathrm{dd}, 1 \mathrm{H}, \mathrm{J}=2.0$ and $13.0 \mathrm{~Hz}), 4.78(\mathrm{~m}, 2 \mathrm{H}), 4.92(\mathrm{t}, 1 \mathrm{H}, \mathrm{J}=2.0 \mathrm{~Hz}), 6.93(\mathrm{~d}, 2 \mathrm{H}, \mathrm{J}=8.1 \mathrm{~Hz})$ and $7.87(\mathrm{~d}, 1 \mathrm{H}, \mathrm{J}=$ 8.1 Hz). Anal. calcd. for $\mathrm{C}_{16} \mathrm{H}_{18} \mathrm{O}_{7}: \mathrm{C}, 51.69$; H, 4.88; Found: C, 51.60; H, 4.94.

5-O-(4-Chlorobenzoyl)-2,3-O-isopropylideneribonic-1,4-lactone (27). Recrystallized in ethyl acetate-diethyl ether (92\% yield), m.p. $163^{\circ} \mathrm{C}$; IR: 1782,1726 and $1384 \mathrm{~cm}^{-1} ;{ }^{1} \mathrm{H}-\mathrm{NMR}\left(\mathrm{CDCl}_{3}\right)$ : $\delta 1.40(\mathrm{~s}, 3 \mathrm{H}), 1.52(\mathrm{~s}, 3 \mathrm{H}), 4.52(\mathrm{dd}, 1 \mathrm{H}, \mathrm{J}=2.0$ and $13.5 \mathrm{~Hz}), 4.66(\mathrm{dd}, 1 \mathrm{H}, \mathrm{J}=2.0$ and 13.5 $\mathrm{Hz}), 4.78(\mathrm{~m}, 2 \mathrm{H}), 4.91(\mathrm{t}, 1 \mathrm{H}, \mathrm{J}=2.0 \mathrm{~Hz}), 7.44(\mathrm{~d}, 2 \mathrm{H}, \mathrm{J}=8.8 \mathrm{~Hz})$ and $7.88(\mathrm{~d}, 2 \mathrm{H}, \mathrm{J}=8.8 \mathrm{~Hz})$. Anal. calcd. for $\mathrm{C}_{15} \mathrm{H}_{15} \mathrm{ClO}_{6}$ : C, 55.14; H, 4.94; Found: C, 55.31; H, 4.97.

5-O-(4-Nitrobenzoyl)-2,3-O-isopropylideneribonic-1,4-lactone (28). Recrystallized in acetone-ethanol (90\% yield), m.p. $158-159^{\circ} \mathrm{C}$; IR: $1766,1740,1532,1382$ and $1354 \mathrm{~cm}^{-1} ;{ }^{1} \mathrm{H}-$ NMR $\left(\mathrm{CDCl}_{3}\right): \delta 1.41(\mathrm{~s}, 3 \mathrm{H}), 1.52(\mathrm{~s}, 3 \mathrm{H}), 4.63(\mathrm{~m}, 2 \mathrm{H}), 4.79(\mathrm{~m}, 2 \mathrm{H}), 4.92(\mathrm{~m}, 1 \mathrm{H}), 8.12(\mathrm{~d}$, $2 \mathrm{H}, \mathrm{J}=8.9 \mathrm{~Hz})$ and $8.32(\mathrm{~d}, 2 \mathrm{H}, \mathrm{J}=8.9 \mathrm{~Hz})$. Anal. calcd. for $\mathrm{C}_{15} \mathrm{H}_{15} \mathrm{NO}_{8}: \mathrm{C}, 55.39 ; \mathrm{H}, 3.04 ; \mathrm{N}$, 4.15; Found: C, 55.53; H, 3.09; N, 4.30.

5-O-(4-Chloro-3-nitrobenzoyl)-2,3-O-isopropylideneribonic-1,4-lactone (29). Recrystallized in ethanol (80\% yield), m.p. $87^{\circ} \mathrm{C}$; IR: 1796, 1720, 1538, 1380 and $1352 \mathrm{~cm}^{-1}$; ${ }^{1} \mathrm{H}-\mathrm{NMR}$ $\left(\mathrm{CDCl}_{3}\right): \delta 1.40(\mathrm{~s}, 3 \mathrm{H}), 1.51(\mathrm{~s}, 3 \mathrm{H}), 4.63(\mathrm{~m}, 2 \mathrm{H}), 4.78(\mathrm{~m}, 2 \mathrm{H}), 4.91(\mathrm{~m}, 1 \mathrm{H}), 7.69(\mathrm{~d}, 1 \mathrm{H}, \mathrm{J}=$ $8.3 \mathrm{~Hz}), 8.04(\mathrm{~d}, 1 \mathrm{H}, \mathrm{J}=8.3 \mathrm{~Hz})$ and $8.45(\mathrm{~s}, 1 \mathrm{H})$. Anal. calcd. for $\mathrm{C}_{15} \mathrm{H}_{14} \mathrm{ClNO}_{8}$ : C, 48.47; $\mathrm{H}$, 3.80; N. 3.77; Found: C, 48.54; H, 3.92; N. 3.69. 


\section{General procedure for the synthesis of 5-O-acylribonic-1,4-lactones (31-35)}

Method A. A solution containing 5-O-acyl-2,3-O-isopropylidene-1,4-lactone $(0.40 \mathrm{mmol})$ in $1.5 \mathrm{~mL}$ of $50 \%$ aqueous trifluoroacetic acid was stirred at $40^{\circ} \mathrm{C}$ for 1.5 hours. The final suspension was concentrated in vacuo and the white residue obtained was co-evaporated with ethanol to remove traces of trifluoroacetic acid. Recrystallization in the solvent indicated below afforded the 5-acyl ribonic lactones as crystalline solids.

Method B. A solution containing 5-O-acyl-2,3-O-isopropylidene-1,4-lactone $(0.40 \mathrm{mmol})$ in $1.5 \mathrm{~mL}$ of $10 \%$ aqueous acetic acid was stirred at $90^{\circ} \mathrm{C}$ for 3 hours. The final suspension was concentrated in vacuo and the white residue obtained was co-evaporated with ethanol to remove traces of acetic acid and recrystallized in the appropriated solvent to give crystalline 5-acyl ribonic lactones.

5-O-Benzoylribonic-1,4-lactone (31). Method A, recrystallized in chloroform-diethyl ether (99\% yield), m.p. $153-155^{\circ} \mathrm{C}$; IR: $3482,3276,1770$ and $1716 \mathrm{~cm}^{-1} ;{ }^{1} \mathrm{H}-\mathrm{NMR}$ (DMSO-d 6 ): $\delta 4.26$ $(\mathrm{m}, 1 \mathrm{H}), 4.46(\mathrm{~m}, 3 \mathrm{H}), 4.58(\mathrm{~m}, 1 \mathrm{H}), 5.64(\mathrm{~m}, 1 \mathrm{H}), 5.93(\mathrm{~m}, 1 \mathrm{H}), 7.53(\mathrm{t}, 2 \mathrm{H}, \mathrm{J}=7.1 \mathrm{~Hz}), 7.68$ $(\mathrm{d}, 1 \mathrm{H}, \mathrm{J}=7.1 \mathrm{~Hz})$ and $7.95(\mathrm{~d}, 2 \mathrm{H}, \mathrm{J}=7.1 \mathrm{~Hz})$. Anal. calcd. for $\mathrm{C}_{12} \mathrm{H}_{12} \mathrm{O}_{6}: \mathrm{C}, 57.14 ; \mathrm{H}, 4.79$; Found: C, 57.30; H, 4.91.

5-O-(4-Methoxybenzoyl)ribonic-1,4-lactone (32). Method B, recrystallized in acetone-ethanol (54\% yield), m.p. $150-151^{\circ} \mathrm{C}$; IR: $1760,1728,1382$ and $1170 \mathrm{~cm}^{-1} ;{ }^{1} \mathrm{H}-\mathrm{NMR}$ (DMSO-d 6 ): $\delta 3.85$ $(\mathrm{s}, 3 \mathrm{H}), 4.26(\mathrm{~m}, 1 \mathrm{H}), 4.40-4.65(\mathrm{~m}, 4 \mathrm{H}), 5.61(\mathrm{~m}, 1 \mathrm{H}), 5.92\left(\mathrm{~m}, 1 \mathrm{H}, \mathrm{D}_{2} \mathrm{O}\right.$ exchange), 7.07 (d, $2 \mathrm{H}, \mathrm{J}=8.5 \mathrm{~Hz}$ ) and $7.90(\mathrm{~d}, 2 \mathrm{H}, \mathrm{J}=8.5 \mathrm{~Hz})$. Anal. calcd. for $\mathrm{C}_{13} \mathrm{H}_{14} \mathrm{O}_{7}: \mathrm{C}, 55.32 ; \mathrm{H}, 5.00$; Found C, 55.30; H, 5.08 .

5-O-(4-Chlorobenzoyl)ribonic-1,4-lactone (33). Method A, recrystallized in acetone-ethanol (99\% yield), m.p. $168-169^{\circ} \mathrm{C}$; IR: 3392, 1768 and $1726 \mathrm{~cm}^{-1} ;{ }^{1} \mathrm{H}-\mathrm{NMR}$ (DMSO-d $\left.\mathrm{d}_{6}\right): \delta 4.27$ (m, $1 \mathrm{H}), 4.40-4.65(\mathrm{~m}, 4 \mathrm{H}), 5.65(\mathrm{~s}, 1 \mathrm{H}), 5.93(\mathrm{~m}, 1 \mathrm{H}), 7.63(\mathrm{~d}, 2 \mathrm{H}, \mathrm{J}=8.4 \mathrm{~Hz})$ and $7.95(\mathrm{~d}, 2 \mathrm{H}, \mathrm{J}=$ 8.4 Hz). Anal. calcd. for $\mathrm{C}_{12} \mathrm{H}_{11} \mathrm{ClO}_{6}$ : C, 50.28; H, 3.87; Found: C, 50.15; H, 3.94 .

5-O-(4-Nitrobenzoyl)ribonic-1,4-lactone (34). Method $\mathrm{B}$, recrystallized in acetone-ethanol (65\% yield), m.p. $176^{\circ} \mathrm{C}$; IR: $3480,3332,1766,1726,1544$ and $1348 \mathrm{~cm}^{-1}$; ${ }^{1} \mathrm{H}-\mathrm{NMR}$ (DMSO$\left.\mathrm{d}_{6}\right): \delta 4.27(\mathrm{~m}, 1 \mathrm{H}), 4.47(\mathrm{~m}, 2 \mathrm{H}), 4.58(\mathrm{~m}, 2 \mathrm{H}), 5.64(\mathrm{~m}, 1 \mathrm{H}), 5.93(\mathrm{~m}, 1 \mathrm{H}), 8.18(\mathrm{~d}, 2 \mathrm{H}, \mathrm{J}=8.6$ $\mathrm{Hz}$ ) and $8.37(\mathrm{~d}, 2 \mathrm{H}, \mathrm{J}=8.6 \mathrm{~Hz}) ;{ }^{13} \mathrm{C}-\mathrm{NMR}\left(\mathrm{DMSO}-\mathrm{d}_{6}\right): 64.5,68.4,68.7,81.9,124.1(2 \mathrm{C}), 130.8$ (2C), 134.7, 150.5, 164.0 and 175.8. Anal. calcd. for $\mathrm{C}_{12} \mathrm{H}_{11} \mathrm{NO}_{8}$ : C, 48.49; H, 3.72; N, 4.71; Found: C, 48.60; H, 3.81; N, 4.81 .

5-O-Acetylribonic-1,4-lactone (35). Method B, recrystallized in ethanol (80\% yield), m.p. $148^{\circ} \mathrm{C}$; IR: 3474, 3288, 1760, 1430 and $1386 \mathrm{~cm}^{-1}$; ${ }^{1} \mathrm{H}-\mathrm{NMR}$ (DMSO-d 6 ): $\delta 2.04$ (s, 3H), 4.10$4.55(\mathrm{~m}, 5 \mathrm{H}), 5.58(\mathrm{~m}, 1 \mathrm{H})$ and $5.87(\mathrm{~m}, 1 \mathrm{H})$. Anal. calcd. for $\mathrm{C}_{7} \mathrm{H}_{10} \mathrm{O}_{6}: \mathrm{C}, 42.22 ; \mathrm{H}, 5.30$; Found: C, 42.28; H, 5.06.

\section{Acknowledgments}

The authors are grateful to FAPESP, CNPq and CAPES for financial support. 


\section{References and Notes}

1. (a) Moncayo, A. Mem. I. Oswaldo Cruz 1999, 94 (Suppl. I), 401. Also on the WHO website at http://www.who.org/tdr. (b) Silveira, A. C.; Vinhaes, M. C. Mem. I. Oswaldo Cruz 1999, 94 (Suppl. I), 405.

2. Tanowitz, H. B.; Kirchhoff, L. V.; Simon, D.; Morris, S. A.; Weiss, L. W.; Wittner, M. Clin. Microb. Rev. 1992, 5, 400.

3. Verlinde ,C. L. M. J.; Merrit, E. A.; Van Den Akker, F.; Kim, H.; Feil, I.; Delboni, L. F.; Mande, S. C.; Sarfaty, S.; Petra, P. H.; Hol, W. G. J. Protein Science 1994, 3, 1670.

4. (a) Aronov, A. M.; Suresh, S.; Buckner, F. S.; Van Voorhis, W. C.; Verlinde, C. L. M. J.; Opperdoes, F. R.; Hol, W. G. J.; Gelb, M. H. Proc. Natl. Acad. Sci. USA 1999, 96, 4273. (b) Aronov, A. M.; Verlinde, C. L. M. J.; Hol, W. G. J.; Gelb, M. H. J. Med. Chem. 1998, 41, 4790 .

5. Souza, D. H. F.; Garrat, R. C.; Araújo, A. P. U.; Guimarães, B. G.; Jesus, W. D. P.; Michels, P. A. M.; Hannaert, V.; Oliva, G. FEBS Lett. 1998, 424, 131.

6. Opperdoes, F. R. Ann. Rev. Microbiol. 1987, 41, 127.

7. (a) Bakker, B. M.; Michels, P. A. M.; Opperdoes, F. R.; Westerhoff, H. V. J. Biol. Chem. 1999, 274, 14551. (b) Bakker, B. M.; Westerhoff, H. V.; Opperdoes, F. R.; Michels, P. A. M. Mol. Biochem. Parasitol. 2000, 106, 1.

8. Vieira, P. C.; Mafezoli, J.; Pupo, M. T.; Fernandes, J. B.; Silva, M. F. G. F.; Albuquerque, S.; Oliva, G.; Pavão, F. Pure Appl. Chem. 2001, 73, 617.

9. Kennedy, K. J.; Bressi, J. C.; Gelbi, M. H. Bioorg. Med. Chem. Lett. 2001, 11, 95.

10. Pavão, F. Master's Degree Dissertation, Institute of Chemistry of São Carlos, University of São Paulo, 1996; p. 93.

11. Fox, J. J.; Wempen, I.; Hampton, A.; Doerr, I. L. J. Am. Chem. Soc. 1958, 80, 1669.

12. Bredereck, H.; Martini, A. Chem. Ber. 1947, 80, 401.

13. Chládek, S.; Smrt, J. Collect. Czech. Chem. Commun. 1964, 29, 214.

14. Ishido, Y.; Nakazaki, N.; Sakairi, N. J. Chem. Soc., Perkin 1 1979, 2088.

15. Ikehara, M.; Uno, H.; Ishikawa, F. Chem. Pharm. Bull. 1964, 12, 267.

16. Sasaki, T.; Minamoto, K.; Tanizawa, S. J. Org. Chem. 1973, 38, 2896.

17. Schmidt, R. R.; Fritz, H.-J. Chem. Ber. 1970, 103, 1867.

18. (a) Hollingsworth, R. I.; Wang, G. Chem. Rev. 2000, 100, 4267. (b) Wong, C.-H.; Kathryn, K. M. Chem. Rev. 2000, 100, 4465.

19. Lederkremer, R. M.; Varela, O. Adv. Carbohydr. Chem. Biochem. 1994, 50, 125.

20. Bhat, K. L.; Chen, S.-Y.; Joullié, M. M. Heterocycles 1985, 23, 691.

21. Bigham, E. C.; Gragg, C. E.; Hall, W. R.; Kelsey, J. E.; Mallory, W. R.; Richardson, D. C.; Benedict, C.; Ray, P. H. J. Med. Chem. 1984, 27, 7176.

22. Enholm, E. J.; Jiang, S.; Abboud, K. J. Org. Chem. 1993, 58, 4061.

23. Camps, P.; Cardellach, J.; Font, J.; Ortuno, R. M.; Ponsati, O. Tetrahedron 1982, 38, 2395.

24. Hanessian, S.; Murray, P. J. Tetrahedron 1987, 43, 5055. 
25. Kold, H.; Lundt, I.; Pedersen, C. Acta Chem. Scand. 1994, 48, 675.

26. Han, S.-Y.; Joullié, M. M.; Petasis, N. A.; Bigorra, J.; Corbera, J.; Font, J.; Ortuno, R. M. Tetrahedron 1993, 49, 349.

27. Hough, L.; Jones, J. K. N.; Mitchell, D. L. Can. J. Chem. 1958, 36, 1720.

28. Rodriguez, J. B. Tetrahedron 1999, 55, 2157.

29. Ogura, H.; Takahashi, H.; Itoh, T. J. Org. Chem. 1972, 37, 72.

30. Szarek, W. A.; Zamojski, A.; Tiwari, K. N.; Ison, E. R. Tetrahedron Letters 1986, 27, 3827. 